Brandeis $\mid$ urearar

brandeis.edu/j-caste
CASTE: A Global Journal on Social Exclusion

Vol. 2 No. 2 pp. $265-280$

October-November 2021

ISSN 2639-4928

https://doi.org/10.26812/caste.v2i2.326

\title{
Ambedkar and the Buddha's Sangha: A Ground for Buddhist Ethics
}

\author{
Timothy Loftus'
}

\begin{abstract}
The sangha is one of the three jewels of the Buddhist tradition. While undervalued in many other Anglophone iterations of Buddhist modernism, Ambedkar's approach to Buddhism placed a reconceptualized sangha at the center. Where traditional accounts often limit the boundaries of sangha to ordained monks and nuns, Ambedkar sought to include all lay Buddhists within its frame. He suggests that the role of the sangha is not, as many traditional accounts might suggest, the personal liberation of the monks and nuns who join it, but instead social service directed toward the community at large. Ambedkar's commitment to the development of a religion that champions egalitarianism naturally lead to his inclusion of women as full participants in his image of the sangha, despite the historically patriarchal limits placed on them in many traditional Buddhist settings. This wide-tent approach to the sangha, along with its emphasis on service and egalitarian principles, are defining features of Ambedkar's unique approach the Buddhist tradition.
\end{abstract}

\section{Keywords}

Ambedkar, Ambedkarite Buddhism, Buddhist ethics, Buddhist sangha, women in Buddhism, Ambedkar and gender

\section{Introduction}

While there exist numerous social scientific treatments of Dr. B. R. Ambedkar's Buddhist conversion movement, Religious Studies treatments remain relatively few. Social scientists have historically approached Dr. Ambedkar's interest in and conversion to Buddhism as instrumental and have framed it as politically

\footnotetext{
'PhD Candidate

Dept. of Religion

Temple University, Philadelphia, Pennsylvania, United States

E-mail: timothy.loftus@temple.edu
}

(C) 2021 Timothy Loftus. This is an open access article distributed under the terms of the Creative Commons Attribution License, which permits unrestricted use, distribution, and reproduction in any medium, provided the original author(s) and source are credited. 
expedient, ${ }^{1}$ while Euro-American Buddhist Studies scholarship has largely ignored Dr. Ambedkar's unique approach to Buddhism. Where it is treated, it has been accompanied by caveats regarding its novelty, with reference to an orthodox "Buddhism" often defined by traditional received Western Buddhism. ${ }^{2}$ This received Buddhism is characterized by its emphasis on meditation and pursuit of individual spiritual liberation and by its emphasis on textual authority. Dr. Ambedkar's modernist approach to Buddhism, though, emphasizes the ethical and meliorative dimensions of the tradition and largely ties its liberation from suffering to engagement, justice, and egalitarianism practiced together with self-cultivation. Combined with Dr. Ambedkar's position from the margins as a Dalit, this difference in emphasis and position has often rendered his Buddhism less than visible in the Euro-American Buddhist Studies academy. This article aims to explicate some of the core Ambedkarite Buddhist theological content from inside the tent of Religious Studies. Specifically, it explores the theological work that the Buddhist concept of sangha, or community, does in service of Dr. Ambedkar's approach to Buddhism. What follows is an exploration of his unique and idealized frame for the sangha, the theoretical roots for his perspective on the saingha, and finally his writing on the place of women in the saingha.

Dr. B. R. Ambedkar outlined four core problems to be solved before the modernization of the Buddhist tradition, the religion he saw as uniquely suited to modernity, could be complete. The first problem relates to clarifying the reasons for the Buddha's renunciation while the second and third ralate to the teachings on suffering and karma, respectively. ${ }^{3}$ The final problem that Ambedkar explicitly set out to settle in his writing on Buddhism, and which will be explored in this article, was related to the proper understanding of the Buddhist saingha, or more specifically, the role of the bhikkhu. ${ }^{4} \mathrm{He}$ asks,

What was the object of the Buddha in creating the Bhikku? Was the object to create the perfect man? Or was his object to create a social servant devoting his life to service of the people and being their friend, guide, and philosopher? This is a very real question. On it depends the future of Buddhism. If the Bhikku is only a perfect man he is of no use to the propagation of Buddhism, because though a perfect man he is a selfish man. If, on the other hand, he is a social servant, he may prove to be the hope of Buddhism. ${ }^{5}$

On display in Ambedkar's framing of this question is his commitment to approaching the Buddhist tradition through the lens of the social. The two loaded choices he presents in answer to the question he poses, those of a selfish and reclusive mendicant or an engaged guide of the people, intentionally reveal his implicit position and frames his presentation in contrast with that of other, here unnamed, presentations of the sangha; presentations that frame the saingha as, in his terms, a "perfect" though "selfish" body. Ambedkar sees this question as critical, or "a very real question," on which the future of Buddhism depends, and as such, can be argued to be the central problem

${ }^{1}$ See: (Zelliot, 2004, p. 168), (Jaffrelot, 2006, pp. 119-142)

${ }^{2}$ See: (King, 2009, p. 161), (Queen et al., 2003, pp. 22-24)

${ }^{3}$ (Ambedkar et al., 2011, p. xxix)

${ }^{4}$ bhikșu (Sanskrit) and bhikkhu (Pāli) -monk or religious mendicant

${ }^{5}$ B. R. Ambedkar, Aakash Singh Rathore, and Ajay Verma, The Buddha and His Dhamma: A Critical Edition (New Delhi ; Oxford ; New York: Oxford University Press, 2011), xxxi. 
related to the creation of his religious movement. Insofar as Ambedkar approaches the buddhadharma as a project aimed at shaping a religion that is compatible with democratic values, the center of his Buddhism is naturally, in some ways, the sangha. For this Buddhism to be this-worldly oriented and other-facing, concerned with the establishment of a moral ground and a religion of principles, he must deal with the reality of monks and nuns who, in their decision to leave the world and remain cloistered in monasteries, have historically often not acted as the "devoted social servant" of the people. In characteristically direct style he states:

The Bhikkhu Sangha in its present condition can therefore be of no use for the spread of Buddhism. In the first place there are too many Bhikkhus. Of these a very large majority are merely Sadhus and Sannyasis spending their time in meditation or idleness. There is in them neither learning nor service. When the idea of service to suffering humanity comes to one's mind every one thinks of the Ramakrishna Mission. No one thinks of the Buddhist Sangha. Who should regard service as its pious duty the Sangha or the Mission? There can be no doubt about the answer. Yet the Sangha is a huge army of idlers. ${ }^{6}$

Ambedkar addresses this problem by applying an hermeneutic of suspicion, suggesting that the Buddha, an eminently rational and care-oriented individual in Ambedkar's estimation, would have necessarily established the original sangha in accord with those qualities. For Ambedkar, a rational Buddha whose activity was animated by a desire to uproot injustice and oppression, grounded as they are in the power imbalance between a priest class and those at the margins, would have necessarily created a saingha driven by an ethic of care; one actively engaged with the laity and one that would model compassion for those around it. The Buddha that Ambedkar is appealing to here is the Buddha who exhorted the bhikkhus to work actively for the welfare of all beings at the end of the first rains retreat. ${ }^{7}$

\section{Sanigha as a Model Community}

In most Euro-American Buddhist approaches to Buddhism, of the three jewels of the Buddhist tradition, the saingha is often given short shrift in favor of a presentation of the jewels of Buddha and dharma. Explorations of the jewel of Dharma has allowed for fruitful academic cross- cultural philosophical investigation and psychological self-help applications in popular approaches to Buddhism. The jewel of the Buddha, likewise, is also given more weight in comparison. A scientifically compatible Buddha who, for the educated and often elite Western receivers of the tradition, can play the foil to the culturally familiar Christian creator God has played a central role in the construction of Buddhism in the West. ${ }^{8}$ For Ambedkar though, the jewel that takes center stage in his modernist reception of the Buddhist tradition is, in some ways,

${ }^{6}$ B. R. Ambedkar, "The Buddha and the Future of His Religion," Dr. Babasaheb Ambedkar Writings and Speeches, Volume 17, Part 2, pp. 107. https://www.mea.gov.in/Images/attach/amb/ Volume_17_02.pdf

${ }^{7}$ Dharmachari Lokamitra notes, "At the end of his first post Enlightenment rainy season retreat, the Buddha exhorted his first disciples to travel the roads and pathways of for the welfare and happiness of the many people (bahujana hitaya, bahujana sukkhaya)." (Lokamitra, 2004)

${ }^{8}$ See (Lopez, 1995) And (Lopez, 2012) 
the sangha. This shift in emphasis from other English-language modernist receptions of Buddhism is perhaps one of the reasons for the relative dearth of literature on Ambedkarite Buddhism in the West. Where Ambedkar sees the sangha as the heart of the tradition, Wester receivers often see little of it in their quest to mine the tradition for its wisdom teachings on liberation for the individual seeking personal spiritual enlightenment. For Ambedkar, the saingha becomes the vehicle through which the work of social transformation, his ultimate goal, can actually take place.

Ambedkar opens his discussion of the Buddhist sangha in The Buddha and His Dhamma by noting the ways in which the Buddha's idea of parivräja differs from that of the "old Parivrajakas." He notes,

The Buddhist Bhikku is primarily a Parivrajaka. This institution of Parivrajaka is older than that of the Buddhist Bhikku. The old Parivrajakas were persons who had abandoned family life, and were a mere floating body of wanderers. They roamed about with a view to ascertain the truth by coming into contact with various teachers and philosophers, listening to their discourses, entering into discussion on matters of ethics, philosophy, nature, mysticism, and so on... These old type of Parivrajakas had no Sangh, had no rules of discipline, and had no ideal to strive for. It was for the first time that the Blessed Lord organized his followers into a Sangh or fraternity, and gave them rules of discipline, and set before them an ideal to pursue and realise. ${ }^{9}$

Ambedkar is keen to contrast, as he presents it, the individual-focused practice of renunciation exemplified by the wandering $s \bar{a} d h u$ tradition with that of his sociallyoriented Buddha. Ambedkar contends that the Buddha's practice of renunciation is special because for the first time it centers human relationships and community, or, as Ambedkar frames it in Enlightenment-inspired terminology, "fraternity." In this sense the Buddha's followers are not renouncing society writ large, but society as conceived and ordered by the Brahminical system. To renounce in this context means to consciously form a new social order that centers a relational morality in place of the individual path to personal liberation as practiced by previous renunciates.

Following the vinaya, Ambedkar taxonomically divides the Buddhist sangha into two parts: the śramenera as anyone who takes the ten precepts and the threefold refuge, ${ }^{10}$ and the bhikkhu, or fully ordained person. Where Ambedkar's presentation takes a unique turn is in his attempts to answer a question regarding the Buddha's intended audience for his ethical teachings. Did the Buddha intend his teachings on prescriptive action only for the bhikkhus and bhikkhunis (female renunciants) or did he intend for those teachings to apply to householders as well? Ambedkar argues that the Buddha had householders as well as monastics in mind. This idea is central to Ambedkar's reconceptualization of the sangha. He intends to make the saingha into an exemplary community that can serve as a guide for the wider society, and as such, he envisions it as necessarily engaged. He notes,

${ }^{9}$ (Ambedkar et al., 2011, p. 222)

${ }^{10}$ "The entrants into the Sangh were divided into two classes: Shrameneras and Bhikkhus. Anyone below twenty could become a Shramenera. By taking the Trisaranas and by taking the ten precepts, a boy becomes a Shramenera." (Ambedkar et al., 2011, p. 223) Rathore and Verma note that Ambedkar is referencing Mahāvagga I: 56 here. 
...the Blessed Lord also knew that merely preaching the Dhamma to the common men would not result in the creation of that ideal society based on righteousness. An ideal must be practical, and must be shown to be practicable. Then and only then do people strive after it and try to realize it. To create this striving, it is necessary to have a picture of a society working on the basis of the ideal, and thereby proving to the common man that the ideal was not impracticable but on the other hand realizable. The Sangh is the model of a society realizing the Dhamma preached by the Blessed Lord. This is the reason why the Blessed Lord made the distinction between the Bhikkhu and the Upasaka. ${ }^{11}$ [emphasis added]

For Ambedkar, the proper motivation for joining the sangha, either as a śramenera or a fully ordained bhikkhu, is to provide service to the world, not to retire from the world in search of personal liberation. It is worth noting that Ambedkar's reconceptualization of the sangha here is similar in some ways to other twentieth century Buddhist modernist reform movements in Asia, including the work of A.T. Ariyaratne and the Sarvodaya Shramandana movement in Sri Lanka and Sulak Sivaraksa's and Buddhadasa Bhikkhu's influence in Thailand, among others. ${ }^{12}$ For Ambedkar, the Buddhist saingha is the social organization par excellence. It required of its members a commitment to equality and a simplicity in living that could serve as a model to all. Ambedkar is keen to dispel what he sees as common misunderstandings that Buddha's teachings were intended only for the bhikkhu. He argues that while references to the bhikkhu are found all over the canonical material, he argues that a rational, care-oriented Buddha would have certainly had the laity in mind when presenting his teachings. He points to the five precepts, the eightfold path, and the päramitās as evidence in themselves that the Buddha was primarily concerned with the whole of his followers, not simply with those who had received full ordination. He states:

Merely because the sermons were addressed to the gathering of the Bhikkhus, it must not be supposed that what was preached was intended to apply to them only. What was preached applied to both. That the Buddha had the laity in mind when he preached: (i) the Panchasila, (ii) The Ashtanga Marga, and (iii) The Paramitas, is quite clear from the very nature of those things; and no argument, really speaking, is necessary. It is for those who have not left their homes and who are engaged in active life that the Panchasila, Ashtanga Marga, and Paramitas are essential... When the Buddha, therefore, started preaching his Dhamma, it must have been principally for the laity. ${ }^{13}$

Ambedkar notes that the historical practice of privileging the sangha resulted in an only loosely organized laity and he argues that while there was a formal ordination ceremony for joining the sangha, there did not exist a similar path of commitment for the laity. A natural consequence of this, he argues, was that members of the Buddhist laity tended toward opportunistic religious seeking. This failure of the Buddhist tradition to create a commitment ceremony, or Dhamma-Diksha as Ambedkar terms

\footnotetext{
${ }^{11}$ Ibid., 232.

${ }^{12}$ See (Queen \& King, 1996)

${ }^{13}$ (Ambedkar et al., 2011, p. 238)
} 
it, was a contributing factor to the decline of Buddhism in India. ${ }^{14}$ In his inclusion of the additional twenty-two vows during his Dhamma-Diksha ceremony in Nagpur in 1956, Ambedkar links his presentation of the dharma with his vision for the saingha and attempts to correct this oversight of the earlier Buddhists by committing the laity to the Buddhist teachings.

The very nature of the bhikkhu for Ambedkar demands social service. He sees it as the primary motivation for taking parivräja and in this sense, his presentation of the Buddha's decision to leave home reflects this. When the Buddha, faced with a decision to accept the Sakya Sangh's decision to wage war on their neighbors or to be exiled from the community as described in The Buddha and His Dhamma, Siddhārtha chooses the latter. He is motivated by a desire to minimize the material and emotional suffering that will result from the decision to wage war. Likewise, in regard to the motivation for the bhikkhu to take parivräja he states,

A Bhikkhu leaves his home. But he does not retire from the world. He leaves home so that he may have the freedom and the opportunity to serve those who are attached to their homes, but whose life is full of sorrow, misery, and unhappiness and who cannot help themselves. Compassion, which is the essence of Dhamma, requires that everyone shall love and serve, and the Bhikkhu is not exempt from it. A Bhikkhu who is indifferent to the woes of mankind, however perfect in self-culture, is not at all a Bhikkhu. He may be something else but he is not a Bhikkhu. ${ }^{15}$

While Ambedkar emphasizes the social responsibilities and the role of compassion in the ethical imperative of the monk, it is worth noting that he does not reject the role of personal religious cultivation. In the story of Siddhārtha's path to Buddhahood, for example, Ambedkar presents Siddhārtha as inducing "his companions to join him in practising meditation"16 and he states, "Siddharth believed that meditation on right subjects led to development of the spirit of universal love." ${ }^{17}$ And at the end of the biographical section of The Buddha and His Dhamma, Ambedkar states clearly that mental self-cultivation is essential to the Buddhist path. He states, "if mind is comprehended, all things are comprehended. Mind is the leader of all of its faculties... The first thing to attend to is the culture of the mind." He goes on, "Whatsoever there is of good, connected with good, belonging to good - all issues from mind... the cleaning of the mind is, therefore, the essence of religion." 18 There are numerous passages in The Buddha and His Dhamma that stress the necessity of self-cultivation, particularly amongst the ordained sangha for true and lasting social change to take

\footnotetext{
${ }^{14}$ On the lack of Dhamma-Diksha, Ambedkar states, "This was a grave omission. It was one of the causes of the which ultimately led to the downfall of Buddhism in India. For this absence of the initiation ceremony left the laity free to wander from one religion to another and, worse still, follow them at one and the same time." (Ambedkar et al., 2011, p. 238)

${ }^{15}$ (Ambedkar et al., 2011, pp. 232-233)

${ }^{16}$ Ambedkar, Rathore, and Verma, 9.

${ }^{17}$ (Ambedkar et al., 2011, p. 9)

${ }^{18}$ (Ambedkar et al., 2011, p. 62)
} 
place and highlight the need for the development of wisdom alongside compassionate action. Ambedkar states:

Is the Bhikkhu to devote himself to self-culture, or is he to serve the people and guide them? He must discharge both functions. Without self-culture he is not fit to guide. Therefore he must be a perfect, best man, a righteous man and an enlightened man. For this he must practice self-culture. ${ }^{19}$

Pradeep Gokhale has noted the ways in which Ambedkar is at times wrongly charged with totally ignoring the role of meditation in his teachings. He has suggested that Ambedkar's subordination of the role of meditation has parallels in other Asian Buddhist modernist movements and suggests that Ambedkar's approach to meditation can be compared to Sulak Sivaraksa's and is consonant with other engaged Buddhist approaches in its presentation of meditation as supplemental to social engagement. ${ }^{20}$

\section{Origins of the Saingha}

I argue that the theoretical origins of Ambedkar's thought regarding the saingha can be found in his work, The Untouchables: Who Were They and Why They Became Untouchables. ${ }^{21}$ While the sangha is not explicitly addressed by Ambedkar in The Untouchables, his perception of who the early Buddhists were is significant for an understanding of his conceptualization of how the saingha should be rightly conceptualized in the present. In The Untouchables, Ambedkar undertakes an historical reconstruction of the conditions that gave rise to untouchability. He concludes, in brief, that contemporary Dalits are heirs to classical-period Indian Buddhists. The preface of the book makes clear that his methods are necessarily limited by a significant dearth of evidence and as such, is more of a hypothesis than a work of historical scholarship. He notes that scholarship in India had traditionally been dominated by Brahmins and consequentially the idea of "untouchability" as an object of study had long been overlooked, leaving little data for use in understanding how the practice of untouchability arose. ${ }^{22}$

Ambedkar sees his efforts, therefore, as a correction, writing the wrongs done by Brahmin scholars of the past and present. In a move that anticipates Foucault and Asad, Ambedkar deploys an historical methodology that skillfully weaves together a reconstructive narrative while skirting the boundaries between evidence-based historical scholarship and speculative fabrication. ${ }^{23}$ He likens his work to that of an archaeologist, who through the piecing together of artifactual data, can reproduce a coherent picture of a city or a paleontologist who can reconstruct an extinct animal based on disparate bones and teeth. ${ }^{24}$

In short, his argument is that the root of untouchability, which according to Ambedkar's theory came into existence as a practice only around $400 \mathrm{CE}$, originates in the "contempt and hatred" of Buddhists by Brahmins. Ambedkar considers and rejects

\footnotetext{
${ }^{19}$ (Ambedkar et al., 2011, p. 232)

${ }^{20}$ (Gokhale, 2020, p. 270)

${ }^{21}$ (Ambedkar, 2018)

${ }^{22}$ (Ambedkar, 2018, p. xi)

${ }^{23}$ For a more detailed treatment of Ambedkar's method of writing history from below, see S. Anand and Alex George's commentary on The Untouchables, (Ambedkar et al., 2019, p. 68)

${ }^{24}$ (Ambedkar, 2018, p. xiv)
} 
arguments that untouchability is rooted in racial or occupational differences and instead argues that it was in the larger social transition from nomadic social organizations to settled agrarian communities that created the conditions in which some peoples found themselves outside of the newly developing village. He terms these people "the Broken Men," who resisted urbanization and lived in tension and conflict with the wealthier and more powerful settled communities. They are "broken" because while previously they had tribal identities within which they found community and power, conflict with the increasingly dominant settled people broke them down into smaller and disparate groups that could no longer effectively resist the power of the settled communities. ${ }^{25}$ In Ambedkar's reading, during the Buddhist golden age of India, which he dates from the Ashokan period to around $400 \mathrm{CE}$, many of those Broken Men, along with much of the subcontinent, adopted Buddhism because it offered a source of authority outside of the Brahminical system, within which they existed at the margins. This marked them as particularly loathsome to the Brahmins in that in addition to their stigmatized status as outsiders to the village, they were also proponents of a rival religious tradition.

In answer to the question of why not all Buddhists became "Untouchables," why only the Broken Men, Ambedkar points to the practice of beef eating amongst the Broken Men, which, in combination with their Buddhist identity, gave rise to their untouchable status. ${ }^{26}$ Ambedkar's thesis here, while perhaps curious at first, is that in competition with Buddhists for supremacy, Brahminical religionists adopted many of the ethical and metaphysical stances of their more powerful Buddhist opponents, often in an exaggerated and imitative way, in a bid to regain power. His argument in this work regarding the power of imitation and its role in the formation of caste is an idea that Ambedkar originally developed and advanced decades earlier in his 1917 work Castes in India where, in reference to French sociologist Gabriel Tarde, he suggests that the practice of endogamy and the power of imitation were the initial key components in the establishment of castes in India. ${ }^{27}$ Here again, he appeals to the power of imitation, in particular in regards to dietary practices, to explain the formation of untouchability. He notes the textual evidence for the existence and widespread practice of beef eating and animal sacrifice (particularly that of cows) in pre-śramanic Vedic India and suggests that the pressure exerted by the ethically oriented śramanic religionists produced an overzealous appropriative response from the Brahmins. Ambedkar theorizes that the Brahmins rejected their increasingly unpopular practice of animal (cow) sacrifice and adopted an even stricter (than the Buddhists), totally vegetarian diet. He suggests that the Buddhist sangha, driven primarily by the ethical practice of ahmisa and by a theological rejection of Vedic ritual injunctions, were practicing an ethically conscious form of mindful eating; consuming meat as it was

\footnotetext{
${ }^{25}$ Ambedkar's argument here strikingly anticipates James Scott's work in The Art of Not Being Governed and Against the Grain: A Deep History of the Earliest States, where he explores the origins of the state and the persistence of stateless people and their resistance to the nation-state project from the margins. See (Scott, 2017) and (Scott, 2009)

${ }^{26}$ See Ambedkar, The Untouchables Who Were They and Why They Became Untouchables, chapter 10.

${ }^{27}$ Ambedkar notes, "This propensity to imitate has been made the subject of a scientific study by Gabriel Tarde, who lays down three laws of imitation. One of his three laws is that imitation flows from the higher to lower or, to quote his own words, 'Given the opportunity, a nobility will always and everywhere imitate its leaders, its kings or sovereigns, and the people likewise, given the opportunity, its nobility." B. R. Ambedkar, Castes in India, Delhi: Siddharth Books, $1945 ; 2009,26$
} 
offered but were not, at the time, strict vegetarians. When the Buddhist golden period ended, this form of strict Brahminical vegetarianism and reactionary cow worship, adopted initially in response to Buddhist hegemony, then appeared to have always already been a Brahminical practice in contradistinction to the less restrictive Buddhist concerns about ethical eating. Taken together, Brahminical hatred of Buddhists and disgust for beef eating created the conditions for the rise of untouchability. Those Broken Men who continued to identify as Buddhists and who remained eaters of beef became literally untouchable. Ambedkar turns to the Manusmriti to demonstrate that Brahminical aversion toward the "broken men" was already established before the dominance of Buddhism in India ${ }^{28}$ and he suggests that as Brahminical power grew and that of Buddhism declined, their aversion developed into the practice of untouchability. He states:

This antipathy can be explained on one hypothesis. It is that the Broken Men were Buddhists. As such they did not revere the Brahmins, did not employ them as their priests and regarded them as impure. The Brahmin on the other hand disliked the Broken Men because they were Buddhists and preached against them contempt and hatred with the result that the Broken Men came to be regarded as Untouchables. ${ }^{29}$

He appeals to various sources of Brahminical textual material to support his claim that the Brahmins harbored a deep-seated hatred towards Buddhists. He again points to the Manusmriti and Sanskrit nātya ${ }^{30}$ works, such as the Mricchakatika, to demonstrate anti-Buddhist animosity. ${ }^{31}$ An example he cites from the Manusmriti states, "if a person touches a Buddhist or a flower of Pachupat, Lokayata, Nastika and Mahapataki, he shall purify himself by a bath." 32

The framing of contemporary Dalits as lineage holders of the anti-Brahminical Buddhist holdouts, the "Broken Men," has several obvious advantages. First it provides a plausible empowering narrative for contemporary Dalits while simultaneously flipping the script on the dominant, Brahminically-inflected version of South Asian history. As such, it narrates a version of history where Dalits are not inheritors of the karmic deeds of their past lives, as Brahminical religionists would maintain, but instead, they are the successors of a people who, for centuries, once ruled over their current dominators. Contemporary Dalit suffering can be contextualized as a low

\footnotetext{
${ }^{28}$ Ambedkar references Manusmriti Chapter 10, verses 51-56. For example:

X.51 - But the dwellings of the Chandalas and the Shvapakas shall be outside the village, they must be made Apapatras and their wealth (shall be) dogs and donkeys.

X.52 - Their dress (shall be) the garments of the dead, (they shall eat) their food from broken dishes, black iron (shall be) their ornaments and they must always wander from place to place... See (Ambedkar, 2018, pp. 25-26)

${ }^{29}$ (Ambedkar, 2018, p. 73)

${ }^{30} n \bar{a} t y a$ - Sanskrit - a play (theatrical), performing arts

${ }^{31}$ On Ambedkar's use of the Mricchakațika for support in The Untouchables, George and Anand note that Ambedkar may be stretching a bit in his reading of anti-Buddhist sentiment. See (Ambedkar et al., 2019, p. 66)

${ }^{32}$ (Ambedkar, 2018, p. 74)
} 
point in an ongoing struggle between the righteous and their corrupt oppressors; not a reflection of some degraded inherent nature. Religiously, it associates the movement with a tradition, or in Sanskritic terms, a sampradāya. More specifically, those Dalits who convert (back) to Buddhism are simultaneously both newly becoming Buddhists while also returning from the wilderness, back to a home they had forgotten they belonged to. In this sense Ambedkar's vision of the sangha is rooted in a pre-Sangh Parivar, bottom-up version of ghar wapsi. ${ }^{33}$

\section{Women in the Sangha}

While Ambedkar's writing often defaults to the traditional epicene masculine pronouns, his awareness of gender inequity was markedly progressive. Drawing on the tradition of the non-Brahmin equality movement instigated by Savitribai and Jyotiba Phule in nineteenth century Maharashtra, Ambedkar's mobilizing efforts amounted to a broad tent movement that reached out to marginalized people in terms of caste, class, and gender and as such it was the first successful large scale mass mobilization movement of "Untouchables" across India. ${ }^{34}$ In Ambedkar's early work, Castes in India, ${ }^{35}$ he argues that functionally, the practice of endogamy is the key defining feature of caste and he suggests that consequently the control of women is fundamental to the maintenance of the caste system. Because caste, in his frame, is principally about regulating and limiting marriage and there are only so many available men or women for marriage at any given time, the policing of women's life choices became essential. He argues that practices like sati (widow burning), enforced widowhood, or childhood marriage arrangements arose as necessary practices for the maintenance of caste in this sense. He points to the Manusmriti frequently to highlight the openly prescribed rules that outline who is allowed to marry whom, and he emphasizes the ways in which women are explicitly described as property in the text. For Ambedkar, to truly understand caste in India an appreciation of the way in which the subjugation of women is at the base is necessary. As Pratima Pardeshi has noted in consonance with Ambedkar's analysis regarding the regulation of women's bodies in the maintenance of caste,

These practices are exploitative of women and thus Ambedkar underlines the fact that castes are maintained through the sexual exploitation of women. It is only through the regulation and control of women's sexuality that the closed character of the castes can be maintained; in this sense, he argues that women are the gateways to the caste system. ${ }^{36}$

\footnotetext{
${ }^{33}$ ghar wapsi-(Hindi) "return home," is a term that refers to the Hindu right's attempts to "reconvert" non-Hindu South Asian people "back" into the Hindu fold. It is based on a Hindutva ideology that maintains that all South Asians were originally, at some point in the past, Hindu before they were forcibly or coercively converted by outside forces. Much of the rhetoric of the proponents of ghar wapsi focuses on the "reconversion" of Christians and Muslims in particular, who are presented as having fallen victim to the depredations of colonial era Christian missionaries and Mughal period Islamic authorities.
}

${ }^{34}$ (Pawar \& Moon, 2008, p. 21)

${ }^{35}$ (Ambedkar, 1945)

${ }^{36}$ Pratima Pardeshi, “Ambedkar's Critique of Patriarchy," in (Ambedkar, 1945) 
And again, in highlighting the ways that Ambedkar's anti-caste position is also necessarily feminist:

The subordination of women will not automatically end with the end of capitalism. Ambedkar argues that to achieve this purpose the caste system and patriarchy will have to be attacked. The subordination of women cannot come to an end in a caste-based society and it is therefore women who must lead the struggle for the annihilation of caste. He sees organic links between the struggle against the caste system and the struggle for the liberation of women. Thus, the idea of women's liberation is intrinsic to his ideology and not a token add-on. ${ }^{37}$

As the first Law Minister of India, Ambedkar's efforts to advance the Hindu Code Bill in 1950 sought to establish protections and rights for women in the areas of marriage and divorce, guardianship and adoption, and inheritance and property ownership, all of which were severely regulated in pre-independence India. He undertook extensive study of the textual and theological justifications behind the orthodox Hindu resistance to gender equity and highlighted the ways in which Hindu textual appeals were illiberal. In short, as Pardeshi has rightfully noted in Ambedkar's feminism, he sought to make political and public what had been personal and private. ${ }^{38}$ This was met with such stiff resistance from his political opponents that his version of the bill was ultimately defeated and it marked the end of his political career. ${ }^{39}$

Given Ambedkar's deep abiding concern for the rights of women and his awareness of the ways in which patriarchy was inextricably linked to the maintenance of a dominant Hindu social order, he was naturally concerned about the undeniable patterns of patriarchal domination in the history of the Buddhist tradition. In a piece published in the Maha Bodhi Journal entitled "The Rise and Fall of the Hindu Woman," in response to what he perceived to be unfair attacks on Buddhist gender inequality, Ambedkar mounts a strong defense of the Buddhist tradition's record on women..$^{40}$ In it, he considers the ways in which the Buddha could potentially be found guilty of oppressing women. First, he turns to a passage in the Mahāparanibbāna Sutta that suggests the Buddha viewed women as objects of potential defilement. ${ }^{41}$

\footnotetext{
${ }^{37}$ Ibid., 144.

${ }^{38}$ See Pratima Pardeshi, "Ambedkar's Critique of Patriarchy," in Gokhale, Classical Buddhism, Neo-Buddhism and the Question of Caste, 144.

${ }^{39}$ For details of the Hindu Code Bill proceedings, see (Keer, 2018, pp. 417-425)

${ }^{40}$ Ambedkar states, "In the journal of the Maha Bodhi for March 1950 there appeared an article on "The Position of Women in Hinduism and Buddhism" by Lama Govinda. His article was a rejoinder to an article which had appeared in Eve's Weekly of January 21, 1950, and in which the Buddha was charged as being the man whose teachings were mainly responsible for the downfall of women in India. Lama Govinda did his duty as every Buddhist must in coming forward to refute the charge. But the matter cannot be allowed to rest there. This is not the first time such a charge is made against the Buddha. It is often made by interested parties who cannot bear his greatness, and comes from quarters weightier in authority than the writer an Eve's Weekly can claim. It is, therefore, necessary to go to the root of the matter and examine the very foundation of this oft repeated charge. The charge is so grave and so vile that the readers of the Maha Bodhi will, I am sure, welcome further examination of it." https://www.mea.gov.in/ Images/attach/amb/Volume_17_02.pdf, 109

${ }^{41}$ Ambedkar references chapter 5 , verse 9 of the Mahāparinibbāna Sutta: "How are we to conduct ourselves, (asked Ananda) with regard to womankind ? As not seeing them, Ananda. But if we should see them, what are we to do ? Not talking, Ananda. But if they should speak to us, Lord,
} 
Ambedkar argues, first, that this passage should be regarded as a later interpolation by male monastics for two reasons. First, he appeals to reason and notes that because of the large gap in time between the events of the sutta and when they were actually written down there is ample occasion for error. This is all the more likely, he suggests, when considering that it was primarily male monastics writing for a male monastic audience. After appealing to Caroline Rhys Davids for support, who also expresses suspicion about the providence of the passage in question, he applies his hermeneutic of suspicion and concludes that any anti-woman sentiments were most likely merely heuristic, aimed at maintaining male celibacy and not literal statements about the nature of women. He states:

There is therefore nothing very extravagant in the suggestion that this passage is a later interpolation by the Bhikkhus. In the first place the Sutta Pitaka was not reduced to writing till 400 years had passed after the death of the Buddha. Secondly, the Editors who compiled and edited them were Monks and the Monk Editors compiled and wrote for the Monk. The statement attributed to the Buddha is valuable for a Monk to preserve his rule of celibacy and it is not unlikely for the Monk Editor to interpolate such a rule.

Ambedkar doesn't stop here though. He then engages in a more rigorous comparative text-historical sutta investigation to determine the passage's authenticity. By comparing other suttas in the Digha Nikāya that contain passages from the Mahāparanibbāna Sutta he notes that none replicate this particular passage. He also notes that Chinese versions of the sutta lack the passage in question. ${ }^{42}$

He then turns to some of the charges made against Ananda at the First Council, namely those that suggest it was he who allowed women into the saingha and as such committed a grave error. Ambedkar again, suggests that this position is inconsistent with the actions and words of the Buddha in numerous other places throughout the sutta material. He offers various examples, noting,

Where are the facts? Two examples at once come to mind. One is that of Visakha. She was one of the eighty chief disciples of the Buddha with the title of "Chief of Alms-givers'. Did not Visakha at one time go to hear Buddha preach? Did she not enter his monastery? Did the Buddha act towards Visakha in the manner he directed Ananda to act towards women? What did the Bhikkhus present at the meeting do? Did they leave the meeting? The second instance that comes to one's mind is that of Amrapali of Vaisali. She went to see the Buddha and gave him and his monks an invitation for a meal at her house. She was courtesan. She was the most beautiful woman in Vaisali. Did the Buddha and the Bhikkhus avoid her? On the other hand they accepted her invitation-rejecting the invitation of the Licchavis who felt quite insulted on that account- and went to her home and partook of her food..$^{43}$

what are we to do ? Keep wide awake, Ananda." B.R. Ambedkar, "The Rise and Fall of the Hindu Woman," https://www.mea.gov.in/Images/attach/amb/Volume_17_02.pdf, 109

${ }^{42}$ B.R. Ambedkar, "The Rise and Fall of the Hindu Woman," https://www.mea.gov.in/Images/ attach/amb/Volume_17_02.pdf, 111.

${ }^{43}$ Ibid., 109. 
While acknowledging that the Buddha did indeed advise the monks to be careful around women, Ambedkar suggests that he did so because his primary concern was with guarding their commitment to celibacy, not with any sense of an inherent inferiority of women. ${ }^{44}$ In an argument that perhaps holds less water, he reasons that the bhikkhuni sangha was made inferior to the bhikkhu sangha because of practical concerns regarding the need for the more experienced male monastics to teach the newer, less experienced women, not because they were considered less than the men. ${ }^{45}$ He saves perhaps most of his energy, though, for contrasting the conditions of women in the Brahminical tradition as presented in the Manusmriti. He states:

It is important to understand the reason why the Brahmins debarred woman from taking Sannyas because it helps to understand the attitude of the Brahmins towards woman which was in sharp contrast with that of the Buddha. The reason is stated by Manu. It reads as follows: - IX. 18. Women have no right to study the Vedas. That is why their Sanskars (rites) are performed without Veda Mantras. Women have no knowledge of religion because they have no right to know the Vedas. The uttering of the Veda Mantras is useful for removing sin. As women cannot utter the Veda Mantras they are as untruth is. Although Manu was later than the Buddha, he has enunciated the old view propounded in the older Dhanna Sutras. ${ }^{46}$

Ambedkar then argues that it is in this context, that of Brahminical oppression of women, that the Buddha's decision to admit women to the sangha should be viewed. He suggests the decision to subordinate women monastics to their male counterparts pales in comparison to the ways in which the Brahminical order subjugates them and that consequently, the Buddha's decisions should be viewed in light of his social context,

By admitting women to the life of Parivrajika, the Buddha, by one stroke... gave them the right to knowledge and the right to realize their spiritual potentialities along with man. It was both a revolution and liberation of women in India... This freedom which the Buddha gave to the women of India is a fact of far greater importance and out-weighs whatever stigma which is said to be involved in the subordination of the Bhikkhunis to the Bhikkhu Sangha. ${ }^{47}$

This concern for the status and place of women in the saingha can be found in The Buddha and His Dhamma as well. Ambedkar dedicates a chapter to the "conversion

\footnotetext{
${ }^{44} \mathrm{He}$ notes, "It is also true that the Buddha was dreadfully keen in maintaining celibacy. He was painfully aware of the fact that, to use his own words, "Women doth stain life of celibacy". But what did he advise? Did he advise the Bhikkhus to shun all contact with women? Not at all. He never put any such interdict. Far from doing any such thing what he did was to tell the Bhikkhus that whenever they met any women, do ye call up the mother-mind, the sister-mind, or the daughtermind as the case may be i.e. regard a woman as you would your own mother, sister or daughter." Ibid., 114.

${ }^{45}$ Ambedkar reasons, "By entrusting the work of training the Bhikkhunis to the Bhikkhus, their relationship became one of teacher and pupil. Now does not the relationship of teacher and pupil involve some authority for teacher over the pupil and some submission or subordination on the part of the pupil to the teacher? What more did the Buddha do?" B. R. Ambedkar, "The Rise and Fall of the Hindu Woman," https://www.mea.gov.in/Images/attach/amb/Volume_17_02.pdf ${ }^{46}$ Ibid., 119.

${ }^{47}$ Ibid., 119.
} 
of women," and narrates a version of the admission of the women in the sangha in direct terms. In his version, Ananda approaches the Buddha on behalf of the Buddha's stepmother, Mahāprajāpatī, to advocate for their admission. The Buddha initially rejects his request, but Ananda repeatedly presses him,

Then the Venerable Ananda asked the Blessed One, 'What can be the ground, Lord, for your refusal to allow women to take Parivraja?' 'The Lord knows that the Brahmins hold that the Shudras and women cannot reach moksha (Salvation) because they are unclean and inferior. They do therefore not allow Shudras and women to take Parivraja. Does the Blessed One hold the same view as the Brahmins? Has not the Blessed One allowed the Shudras to take Parivraja and join the Sangh in the same way he has done to the Brahmins?...' ${ }^{48}$

The Buddha is quick and forceful in his reply, "Ananda! Do not misunderstand me. I hold that women are as much capable as men in the matter of reaching Nibbana. Ananda! Do not misunderstand me, I am not an upholder of the doctrine of sex inequality." ${ }^{49}$ The Buddha then, following Ambedkar's logic in the "The Rise and Fall of the Hindu Woman," goes on to explain that his previous refusals to admit women into the sangha were based on practical concerns and not because he felt women inferior. ${ }^{50}$

Ambedkar's presentation of Siddhartha's wife, both in the time before his decision to take parivrājo $\bar{a}$ where she is depicted as a supportive companion, and after his return, when she chastises him for his absence as well as the way in which his stepmother initially resists his decision to leave home but eventually gives her blessing all reflect Ambedkar's commitment to humanizing the women of the life story. Siddhartha's wife, Yaśodharā, responds to the news of her husband's decision to leave not with tears and grief, but with strength,

With full control over her emotions, she replied, 'What else could I have done if I were in your position? I certainly would not have been a party to a war on the Koliyas. Your decision is the right decision. You have my consent and my support. I too would have taken Parivraja with you. If I do not, it is only because I have Rahula to look after. I wish it had not come to this. But we must be bold and brave and face the situation..." (Ambedkar et al., 2011, p. 23)

Ambedkar depicts her not only accepting his decision, but granting her consent and blessing; a markedly progressive reversal of traditional gender roles not only for the fifth-century BCE but for contemporary South Asia as well.

\section{Conclusion}

Ambedkar accomplishes much of the work of establishing his new Buddhism through the construction of his re-conceptualization of the Buddhist sangha. The story of Buddhism in the West has often been told through the lens of the contemplative, filtered by the discourses of modernity and the biases toward individualism and meditation that come with them. The saingha, in this reading, is a support for the individual to achieve personal liberation through self-cultivation and is often ancillary

\footnotetext{
${ }^{48}$ (Ambedkar et al., 2011, p. 108)

${ }^{49}$ Ibid., 108.

${ }^{50}$ Ibid., 108.
} 
to that project. The reception of Buddhism could perhaps be as compellingly told through the lens of sangha as its monastic orientation has given incredibly detailed thought about how to function in intentional social settings via the vinaya, an exhaustive treatment of pragmatic ethics as applied in monastic communities. This is how Ambedkar is approaching the tradition, with the sangha at the center. His decision to favorably position the Dalit community in India within a long historical arc, that of the civilization struggle between a "religion of rules" called Brahminism and a morally-oriented, egalitarian Buddhism, supplies much-needed ground for his nascent pragmatic religious movement. He appeals to the early sangha to demonstrate that, as Buddhists, they were once dominant in India and commanded the respect and fear of the Brahminical religionists. In his reading, they articulated a universalizable ethic of care, that, thanks to the Buddha's rationality and commitment to compassion, is as applicable today as it was 2500 years ago.

Ambedkar's historical reconstruction project, which seeks to read a universalizable ethic back into ancient Indian history was not limited to his movement alone. Many of the late nineteenth and early twentieth century Indian renaissance figures, such as Vivekananda and M. K. Gandhi, were engaged in similar reconstructive projects. Where their projects sought to ground their ethical frame in Vedāntin non-dual spirituality, Ambedkar appeals to a pragmatist-inspired universalizable morality grounded in the śramana tradition's critique of Brahminist religion. Ambedkar's commitment to a meliorative new Buddhism places the sangha on a pedestal in an effort to model a community composed of individuals who are working toward egalitarianism and a just social order. As such, Ambedkar's chief conversation partner is Marx, with whom he agrees about the end, the dissolution of private property, but not about the means. ${ }^{51}$ For Ambedkar, the means is the Buddhadharma, with its therapeutic project for the individual and its social program in the form of the sangha that can affect real change at the base. Ambedkar's sense that religion, in the form of an enlightened religion of principles, is necessary for moral orientation marks the divergence of his thought from that of Marx.

Ambedkar displayed a surprising awareness and concern for the upliftment of women in India at the time. As Pawar and Moon note, ${ }^{52}$ Ambedkar's advocacy for women's rights predates his time in America, suggesting that his family background, his exposure to Phule's work, and his personal disposition all played a role in his awareness in this regard. He portrays the Buddha in The Buddha and His Dhamma as also being explicitly concerned for the welfare of women and goes out of his way, as Fiske and Emmrich note,${ }^{53}$ to depict a Buddha who shows no patriarchal prejudice and a sangha with humanized women represented.

\section{References}

Ambedkar, B. R. (1945). Castes in India. New Delhi: Siddharth Books.

- (2018). The Untouchables: who were they and why they became Untouchables. New Delhi: Maven Books.

\footnotetext{
${ }^{51}$ See (Singh Rathore, 2007)

${ }^{52}$ (Pawar \& Moon, 2008, pp. 157-158)

${ }^{53}$ Adele Fische and Christoph Emmrich, "The Use of Scriptures in B. R. Ambedkar's The Buddha and His Dhamma," in (Reconstructing the World : B. R. Ambedkar and Buddhism in India., n.d., p. 117, fn 107)
} 
Ambedkar, B. R., George, A., Anand, S., \& Ilaiah, K. (2019). Beef, brahmins, and broken men: An annotated critical selection from the Untouchables, who were they and why they became untouchables? New Delhi: Navayana; New York: Columbia University Press.

Ambedkar, B.R., Rathore, A.S., \& Verma, A. (2011). The Buddha and his dhamma: a critical edition. New Delhi: Oxford University Press.

Gokhale, P. (2020). Ambedkar and modern Buddhism: continuity and discontinuity. In P. Gokhale (Ed.), Classical Buddhism, Neo-Buddhism and the question of caste. New Delhi: Routledge India, pp. 257-274.

- (2021). Classical Buddhism, Neo-Buddhism and the question of caste. New Delhi: Routledge India.

Jaffrelot, C. (2006). Dr Ambedkar and untouchability: analysing and fighting caste. Delhi: Permanent Black.

Jondhale, S., \& Beltz, J. (Eds.). (n.d.). Reconstructing the world: B. R. Ambedkar and Buddhism in India. New Delhi; New York: Oxford University Press, 2004.

Keer, D. (2018). Dr. Ambedkar: life and mission. Mumbai: Popular Prakashan Press.

King, S. B. (2009). Socially engaged Buddhism. Honolulu: University of Hawai'i Press.

Lokamitra, D. (2004). The centrality of Buddhism and education in developing Gross National Happiness. In Karma Ura, Karma Galay, \& Center for Bhutan Studies (Eds.), Gross national happiness and development: proceedings of the first international seminar on operationalization of Gross National Happiness. Thimpu: Center for Bhutan Studies, pp. 472-482.

Lopez, D. S. (Ed.). (1995). Curators of the Buddha: the study of Buddhism under colonialism. Chicago: University of Chicago Press.

- (2012). The scientific Buddha: his short and happy life. New Haven: Yale University Press.

Pawar, U., \& Moon, M. (2008). We also made history: women in the Ambedkarite movement. New Delhi: Zubaan.

Queen, C. S., \& King, S. B. (Eds.). (1996). Engaged Buddhism: Buddhist liberation movements in Asia. Albany: State University of New York Press.

Queen, C.S., Prebish, C.S., \& Keown, D. (Eds.). (2003). Action dharma: new studies in engaged Buddhism. New York: Routledge Curzon.

Scott, J.C. (2009). The art of not being governed: an anarchist history of upland Southeast Asia. New Haven: Yale University Press.

- (2017). Against the grain: a deep history of the earliest states. New Haven: Yale University Press.

Singh Rathore, A. (2007). What Can Buddha Teach a Marxist?. In M. Bhalchandra \& A. Singh Rathore (Eds.), Buddhism and the contemporary world: an Ambedkarian perspective. New Delhi: Bookwell, pp. 97-106.

Zelliot, E. (2004). Ambedkar's world: the making of Babasaheb and the Dalit movement. New Delhi: Navayana Press. 